\title{
23
}

\section{The role of the Assembly of Christian Churches in Fiji in the 2006 elections $^{1}$}

\section{Lynda Newland}

Towards the end of the polling week of the 2006 election, the Assembly of Christian Churches in Fiji (ACCF) ran a full-page advertisement in the Fiji Times. On the right side of the page was a Christian cross, below which the Fiji flag flew over a map of Fiji. The text on the left side of the page ran:

THE ASSEMBLY OF CHRISTIAN CHURCHES IN FIJI (ACCF) IS REQUESTING CHURCHES

that we all please go $r$

and vote during this election!

Note: PARLIAMENT IS THE SUPREME LAW MAKING BODY OF THIS NATION.

It is God's Will that the Laws of this Land are based on the Laws of God!

IT IS THEREFORE THE DUTY OF ALL CITIZENS OF THIS NATION TO ELECT A GOD-FEARING \& PROVEN PRIME MINISTER ${ }^{2}$

whose party will make righteous laws

Prov 29:2

When the righteous are in authority the people rejoice:

But when a wicked man rules, the people groan. $\mathrm{NKJV}^{3}$

GOD IS WITH US

when we build our nation according to His ways!

BUT NATION BUILDING WITHOUT GOD IS A REWARDLESS LABOUR!

Ps127:1

Unless the LORD builds the house, they labour in vain who build it;

Unless the LORD guards the city, the watchman stays awake in vain NKJV

In nation building, Fiji must be ruled 
By the laws of God given at

Mt Sinai and at Calvary.

Building with the practice of compromising Christian and non-Christian values

as already reflected in the Constitution ${ }^{4}$

is misleading the nation to stand on false foundation

which is demonic and distasterous [sic] in nature.

THIS WILL SURELY BRING CURSES UPON THE NATION:

Droughts and famines! Earthquakes and tsunamis!

Poverty and slavery! Diseases and Deaths!

(Amos 4: 7-11)

Healthy Nation Building should be founded on God's Law

which reflects the higher and eternal values of the Kingdom of God

LOVE JUSTICE PEACE

RECONCILIATION UNITY

WE THEREFORE HAVE NO OPTION BUT TO VOTE FOR THAT LEADER WHO CHERISHES AND LIVES BY GOD'S LAWS

Only then would we be assured of Peace and Prosperity

(Ezekiel 34: 22-31) ${ }^{6}$

Putting aside questions of the legality of this kind of advertisements during the election - when political advertising is banned - the advertisement raises questions about the style of governance proposed for Fiji. It is indicative not of the views of a small fundamentalist section of the community, but of major and influential Christian churches, including the Methodist Church, the Assemblies of God (AOG), the Christian Mission Fellowship (CMF), the Church of God (COC), and a host of other Pentecostal churches, all of which form the membership of the ACCF. ${ }^{7}$ For people living in Fiji, its message was clear: vote for Laisenia Qarase and the SDL (Soqosoqo Duavata ni Lewenivanua) or face spiritual and material disaster. Moreover, it was a clear call to mobilize Fijians to participate in the election in order to achieve a Christian state in which Fijians would hold paramountcy. The advertisement relied heavily on established cultural structures and values in calling the Methodist and Pentecostal churches to respond to issues within the Fijian community. ${ }^{8}$ In this chapter, I explore the common ideological framework of the member churches of the ACCF in relation to the political sphere; and the way it informed the religious rhetoric of the 2006 election.

To understand the underlying logic of these churches, it is necessary to understand how Christianity has become central to Fijian identity and 
the values it implies for Fijians. Methodism first came to Fiji through the Wesleyan Methodist Missionary Society in $1835 .{ }^{9}$ The conversion of Cakobau, a paramount chief, was pivotal for the missionaries, as large numbers of conversions followed. Called lotu (religion), Methodism became appropriated to such an extent that it has become viewed as one of the three pillars of Fijian society and culture, of which the other two pillars are the vanua (land and community) and matanitu (chiefly system).$^{10}$ The introduction of Catholicism, Anglicanism, Presbyterianism, Seventh-Day Adventism and, later, Hinduism, Sikhism, and Islam, brought by the indentured labourers, meant that religion in Fiji quickly became pluralistic, but the majority of indigenous Fijians have remained Methodist. Current figures suggest that 93 per cent of the Methodist Church members are Fijian. ${ }^{11}$

If the Methodist Church has remained the largest Christian church - with 36.3 per cent of the total population of Fiji - it has, since the 1960s, also played an increasingly important political role. Before then, indigenous Fijians were tied to their villages, and obliged to provide services for the chiefs under the Fijian Regulations. With the abolition of the regulations in the mid-1960s, the strength of the rural chiefly order was eroded, with the result that many Fijians migrated to urban areas. During this process, the Methodist Church also became progressively more influential in the political sphere. ${ }^{12}$

To begin with, many politicians and political agitators have been trained as pastors in the Methodist Church, and, therefore, their politics are informed by a combination of Fijian cultural values, the specific type of Methodism that arrived with the missionaries, and by more recent contact with the Middle East. For instance, in the 1970s, Sakeasi Butadroka, the founder of the Fijian Nationalist Party and a politician who was vocal in fighting for Fijian paramountcy, was a Methodist lay preacher. ${ }^{13}$ While he and his party advocated the deporting of Indo-Fijians back to India, Fijian soldiers returning from peacekeeping in the Middle East brought back reports about Israel. According to Garrett, this revived the Methodist emphasis on Sabbatarianism, the Old Testament notion that the seventh day should be a day of rest, in conjunction with Fijian ideas of tabu, where holiness is associated with prohibition. The ideas that the descendants of the indentured labourers should return to India with their idolatrous religions and that Sunday should 
be an enforced day of rest became central themes for the increasingly political rhetoric of the taukei. ${ }^{14}$

Then, in 1987, coup leader Sitiveni Rabuka claimed he was 'Moses of the Chosen People' and that Christianity should be the official religion of Fiji - at the expense of the Indo-Fijians who were represented as heathens who threatened to overtake Fijian land. ${ }^{15}$ Aligned closely with the Methodist Church, Rabuka invited people such as his kinsman and Methodist minister, Raikivi, to serve as a minister in the interim government. ${ }^{16}$ Further, while Rabuka was filmed preaching his politics in his role as pastor for the Methodist Church, Indo-Fijians were harassed and beaten in disturbances on the streets of Suva. ${ }^{17}$ Meanwhile, the general secretary of the Methodist Church and supporter of Rabuka, Reverend Manasa Lasaro, was central in influencing the military's decision to impose the Sunday Decree, which prohibited all work on Sundays. In response to the interim government's attempt to lessen the impact of the decree, roadblocks were set up at 70 places around Suva. At the same time, a split was deepening between rival factions in the Methodist Church, with the consequence that the president of the church, Rev. Josateki Koroi, who opposed Rabuka, was ousted in favour of Reverend Ratu Isireli Caucau. ${ }^{18}$

Looking back at that period, Lasaro explained that he would still 'like to see that Sunday is kept a special day in this country'. ${ }^{19}$ For him, keeping Sunday as a day of rest is a sign that moral values are kept and maintained. The 1980s were about Fijians finding a voice:

We don't want to be pushed around by any other country, no matter who it is: the colonial government or other foreign countries which are very active in this region, particularly New Zealand and Australia and of course India... Even now the feelings are still strong... What Rabuka did [the 1987 coup] sort of opened the door to indigenous Fijians. Now, with the present government [under SDL], we have seen affirmative action and since then we find a lot of Fijians going into commercial activities, a lot of Fijians have gone to higher educational institutions, a lot of Fijians have started asking questions about their own destiny as a people...

Here, Lasaro combines the politics of maintaining indigenous identity in the face of the forces of globalization with the religious and moral expression of keeping Sunday as a day of rest. Although Lasaro seemed to be arguing that it was not so much the Indo-Fijian community that was to blame for the threats 
to indigenous identity, but foreign governments, in an interview conducted a few days before, he had noted:

Fijian interests are not exclusive to Fijians. Traditionally, Fijians are a very caring community. They will inconvenience themselves to accommodate the needs of their guests and friends. But the impact of economic and social changes has changed this dramatically in terms of property ownership; Fijians feel that sooner or later they will - what they hold so dear to them will be taken away by somebody else, whether he's European, Indian or anybody else for that matter. ${ }^{20}$

The perception of Fijians as the authentic landowners and Indo-Fijians as guests strongly resonates with the view that the ACCF has placed at the centre of its ethos. However, it differs in that Lasaro's emphasis remains on a fear that Fijian land and, by association, their culture, will be taken away from them by foreigners. By contrast, the ACCF emphasises the importance of Fijian unity, in accordance with God's plan.

Despite the visibility of Methodist Church leaders in politics, the church's dominance has not remained uncontested by those Fijians who converted to other denominations. While Pentecostal and evangelical churches had been entering Fiji since the Assemblies of God was first established in 1926, their numbers burgeoned after independence in $1970^{21}$ and most of their converts have been Fijian Methodists. In the villages, such churches were perceived as threatening the chief and the chiefly system, ${ }^{22}$ and, before 1987 , they had to be registered. Now, however, they are free to establish themselves, despite periodic calls from the Methodist Church for their numbers to be limited. Thus, the post-election coup led to Methodist leaders undertaking a different strategy and spearheading the unification of many of these churches with the Methodist Church under the umbrella organisation, the ACCF. ${ }^{23}$

The 2000 coup demonstrated that sentiments from 1987 remained strong in parts of the Fijian community, despite much of the community rejecting the arguments of George Speight, or no longer viewing a coup as an acceptable way to achieve Fijian ethno-nationalist objectives. This became clear when the actions of Christian leaders differed during and after the coup. For example, Rev. Ratu Epeli Kanaimawi, head of the Worldwide Church of God and a chief of Cakaudrove, led the Great Council of Chiefs into a meeting of mediation with Speight. ${ }^{24}$ Meanwhile, Reverend Kurulo, head of the Christian Mission 
Fellowship, wrote to Speight to demand the release of the hostages, and called prayer meetings. Speight then asked Kurulo for a reconciliation meeting to be held at parliament, at which a group of pastors spoke with him and visited the hostages. ${ }^{25}$ While the timing of Kurulo's visit is not clear, it was reported that leaders from the Methodist Church, All Nations, and Apostles Gospel Outreach Fellowship International (AGOFI) participated in a 'Festival of Praise' at the parliamentary complex. ${ }^{26}$

Churches such as the Seventh-Day Adventists, ${ }^{27}$ the AOG, Fiji, the CMF, the United Pentecostal Church International of Fiji, and the Anglican Church denounced the coup in advertisements in the The Fiji Times and the Daily Post. ${ }^{28}$ The president of the Methodist Church, Reverend Tomasi Kanailagi, also took out a full-page advertisement which said that, while Speight's terrorist activities could not be supported, the Methodist Church supported the interim government, because all of Speight's objectives had been met, ${ }^{29}$ a view often reiterated during the coup. ${ }^{30}$

As a result of feelings that 'the Fijian people were very much fragmented', leaders from the AOG made a traditional approach to Rev. Kanailagi and asked him to call a meeting of churches, the consequence of which was the formation of the ACCF. ${ }^{31}$ Pastor Tamani, an influential leader in the CMF, noted that, 'we wanted to prove to the Great Council of Chiefs that these small churches, we can work together. The problem is not in the church. The problem is in leadership'. ${ }^{32}$ In this way, the member churches of the newly established ACCF shared the vision of uniting the indigenous Fijian community into a political force through the unity of churches as part of God's plan. If the Methodist and Pentecostal God is the spiritual pinnacle of the ACCF, the administrative organization is chaired by a leading member of the Methodist Church: in 2006, that member is Reverend Waqairatu, the Methodist Church's assistant general secretary.

In the view of ACCF leaders, the wounds between Fijians must be healed before any healing of the nation can be undertaken. ${ }^{33}$ Such a view is predicated on the continuing theme that Fijians as the indigenous landowning people should have privileges over and above other Fiji citizens, particularly IndoFijians, who are viewed as guests. This was echoed in an interview with Rev. Matalomani, Coordinator for the ACCF: 
Forget about the Indians. It's amongst the Fijians and, if the Fijians are unhappy, the Indians will be in trouble too because we will not give up our land. When the Fijians are satisfied that their land, their right to belonging comes back to them, we are a giving people, we are an accommodating race, and it is only the differences in the political field that are blowing out the racial differences. ${ }^{34}$

This view is typical in that it continues to promote the idea that Fijian landownership is threatened by changes in the law, despite the fact that, by 1992, 87 per cent of the land in Fiji has been categorized as Native Land ${ }^{35}$, and despite the protection of Fijian land in the constitution. In contrast to Rabuka and Lasaro, people like Reverend Matalomani no longer consider Indo-Fijians an imminent threat. Rather, they view Fijians as having suffered primarily from colonization, when laws robbed Fijians of land that was rightfully theirs, and they consider, therefore, that such laws need to be revisited. ${ }^{36}$ However, once again, the threat to Fijian unity is seen to come from outside.

The ACCF's vision statement is that ACCF members must strive to make Fiji 'God's Treasured Possession', as a nation that honours and glorifies God. Further elaborated into four principles, the mission statement notes that all flocks must unite, members should live God's way of love, leadership should be God-fearing, and Fiji should be reconciled for peace and prosperity. Reverend Kanaimawi (the acting chairman at the time of interview) further explained that the last principle is drawn from Corinthians II:5, which describes God's reconciliation to humanity through Christ. ${ }^{37}$ The principle also resonates with concerns regarding the reconciliation of Fijian communities (vanua) after the 2000 coup, and echoes the Fijian notion of the good chief, who, by virtue of his wisdom, bestows peace and prosperity upon the village, thus revealing a conjunction between ideas about chiefliness and lotu.

In advocating that members strive for a nation that honours and glorifies God, the vision statement implicitly endorses the notion of a Christian state, where all laws are based on Christian teachings as interpreted by the member churches of the ACCF. While this is the same stance that Rabuka held in $1987,{ }^{38}$ many accept that, if Fiji were to become a Christian state, those who are not Christian should be tolerated, providing they conducted themselves according to Christian law. ${ }^{39}$ The notion of the exclusively Christian state has periodically emerged since the 1987 coups, and it reappeared in March 2006 
in an ACCF project aimed at healing the land, which then became a call to make each province in Fiji Christian.

'Healing the land' is the core project of the Evangelical Fellowship, recently renamed the Covenant Evangelical Church and a member of the ACCF. Under the project, a team visits the provinces to reconcile chiefs and all the Christian denominations in the villages, and to eradicate social ills. Reverend Kanaimawi, who was acting chairman of the ACCF in 2005, described them as:

very skilled in healing the land. They go out to the village and get all the villagers, irrespective of what church they are, look at their problems, do a spiritual mapping, map out where the devil has been influential - whether it's a killing field in one place or it's where they worshipped demons in the past - and then they cleanse those out. Then the people repent for what they have done and ask God to come in and the whole village just transforms itself. ${ }^{40}$

Critics have noted that 'healing the land' includes exorcising gods of other religions (including Hinduism) from the land, and supporting the political rhetoric of the SDL; a counter to the army's truth and justice exercise. ${ }^{41}$ Only two months before the 2006 election, Ratu Soqosoqo, an influential member of the ACCF and Kadavu chief, was reported as saying that, 'If we cannot make Fiji a Christian country then we chiefs should make our territories and everyone in it Christians'. ${ }^{42}$

While the provinces experience a particular kind of Christian revival, Fijian allegiance to the increasing diversity of emerging Pentecostal/evangelical churches is not, according to Kanaimawi, considered a threat to the established churches, but rather 'a link for us to some greater things that God is preparing'. ${ }^{43}$ This statement demonstrates the ACCF's strategy of incorporation and cooperation between churches as much as it does the theological importance of the return of Jesus to harvest souls at the 'End-Times', in which most of the member churches believe. Indeed, as almost all these churches except the Methodist Church are Pentecostal/evangelical, with roots in the US Pentecostal movement, their theology is based on the idea of being born again with the entry of the Holy Spirit and the conviction that the End-Times, when Christians will be saved and havoc wreaked upon the earth and unbelievers, are near. ${ }^{44}$ The extent to which most member churches are theologically similar enables the ACCF to draw upon and coordinate the different strengths of the churches in different 
activities. For instance, the CMF has ACCF support in inviting international evangelists to Fiji, and the Covenant Evangelical Church conducts ceremonies to heal the land in the provinces on the ACCF's behalf. ${ }^{45}$

Under the previous government, the ACCF worked closely with government and was perceived as a think-tank for the Prime Minister. ACCF leaders justified this as furthering the project of reconciliation among Fijians, which is criticized by those arguing for ethnic equality. ${ }^{46}$ Certainly, the Prime Minister is known for his devout Methodism, and his comments before the election showed his commitment to ACCF principles. He argued the need for a Fijian prime minister and for the notion that Fiji was a nation of communities rather than a nation of individuals, where communal needs (and particularly those of Fijians) needed to be respected over and above the individualism that he perceived in human rights, saying:

Now for the Fijian people, we need to be acutely aware that democracy in terms of every individual being equal in their basic rights and freedom is quite different from the value systems that provide the basis for traditional Fijian society. ${ }^{47}$

According to Qarase, the fact that Fijians were both numerically 'the majority community' and the landowners meant that the Fijian people should be consulted first over national issues. If this suggests a belief in Fijian paramountcy, the SDL manifesto openly expresses the values behind their objectives as:

1) The ideals and principles of the Christian faith

2) Respect for the Vanua and the cultures and traditions of the indigenous Fijians and Rotumans

3) Respect for the cultures, traditions and religious beliefs of other communities in Fiji

4) Recognition for the paramountcy of indigenous Fijian and Rotuman interests, as proclaimed in the Constitution

5) Respect for legal authority and law and order

6) Respect for human and group rights

7) Honesty in public life and general standards of conduct, which reflect our fundamental beliefs. ${ }^{48}$

With Christianity at the apex of SDL values, SDL uses the symbol of the dove to represent their commitment to Christianity, but, for Fijians, this is clearly a reference to a Christianity embedded in the particular brand of Fijian cultural values propagated by the ACCF. Reflecting ACCF concerns, points 
1, 2, and 4 all show that the SDL give priority to indigenous Christian Fijians and Rotumans and their communities over other citizens and individual rights in Fiji. ${ }^{49}$ Likewise, point 6 suggests that group rights should be considered as much as human rights, which are often perceived by ACCF members as individualistic and therefore foreign. ${ }^{50}$ In addition, if the SDL shares its ideology with the ACCF, their allegiance is also displayed openly in political events. For example, religious leaders from the Methodist Church and the AOG led the prayers at the launch of the SDL manifesto at a rally in Suva. ${ }^{51}$

As the turn-out in the elections steadied, the ACCF advertisement discussed earlier, appeared in The Fiji Times, a clear call to indigenous Fijians to vote in support of Qarase and the SDL, and a sign of ACCF's continued participation in the political sphere. Many ACCF principles appeared in this advertisement, with particular emphasis on mobilizing members to vote for God-fearing leadership in order that they may live by Christian laws, especially in response to the constitution's tolerance of homosexuality. ${ }^{52}$ The latter became publicized in a local case in which an Australian tourist and a local were sentenced to two years' prison for homosexuality. The High Court over-rode the sentence by referring to the constitution, which effectively legalizes private consensual homosexual relationships. In response, the Methodist Church publicized its rejection of homosexuality as a civil right by organizing a protest march in Nausori, with the intention of organizing further marches around the country, a move supported by the AOG ${ }^{53}$ Reverend Waqairatu was further reported as saying that homosexuality could only be eradicated if everyone was converted to Christianity or other religions. ${ }^{54}$ In support, the ACCF leadership sent a letter to the government, arguing against 'all sexual perversions that somewhat has [sic] been encouraged by the so-called 'sexual orientation' clause in the Constitution Section 38 (2) (a)'. ${ }^{55}$ Commonly viewed as foreign, this clause is perceived as threatening the morality of the Fijian community and disengaging them from God's blessings. ${ }^{56}$

Thus, the ACCF's concerns about Fiji legislation relate specifically to existing laws about land, reconciliation between Fijians, and sexual morality, as instances of the need to correct the relationship of indigenous Fijians to each other and to God. In the leadership's view, when the relationship with God is correct, all else will fall into place (a concept I have heard many times when 
interviewing ACCF leaders). Notwithstanding this view, the advertisement in the election showed that the ACCF leaders were also aware that Christians belonging to ACCF churches needed to be mobilized to vote for the correct political leader. Given their close relationship and shared vision with Qarase and the SDL, the ACCF leaders were faced with a potential problem over and above that of ensuring that a Fijian prime minister was elected: the problem being that, if Fijians were not mobilized into voting and the Indo-Fijian Fiji Labour Party (FLP) were to win, the political influence of the ACCF would likely cease altogether.

After the election, Qarase thanked God for his victory, saying, 'I would like to acknowledge the hand of God for the victory. I believe God has a plan for Fiji and the SDL is part of that plan for Fiji'. ${ }^{57}$ Elsewhere, he is reported as thanking 'the Christian churches and people for their prayers and members of the Great Council of Chiefs for their support', saying that he believed, 'it is the Lord's choice that allowed his party to remain in power for another term'. ${ }^{58}$ The swearing-in was opened with Methodist prayers. Many of Qarase's ministers are Methodists, including Josefa Vosanibola, Ratu Meli Saukuru, Misaele Weleilakeba, and Jone Waqairatu; the last of whom is also the brother of Reverend Waqairatu, assistant general secretary of the Methodist Church and chairman of the ACCF. ${ }^{59}$

Therefore, it might have been a surprise for the ACCF leadership that, despite Qarase's belief in the need for a Fijian government to promote Fijian interests and his preference for the FLP to stay in opposition, ${ }^{60}$ he offered the opposition seats in the cabinet. ${ }^{61}$ As the offer was perhaps a tactical manoeuvre, Qarase was himself a little surprised that the FLP accepted. ${ }^{62}$ For his part, Kanaimawi noted that a multiparty cabinet would not work, but that it was 'worth giving it a try ${ }^{63}$ Given the oppositional aspirations of the two parties, whereby the SDL wishes to promote Christian and Fijian interests, while the FLP seeks to promote Indo-Fijians as citizens with equal political rights, the move towards a multiparty cabinet is indeed ambitious.

The rhetoric of the ACCF's advertisement thus draws from culturally accepted ideas about how to bring God's blessings to Fiji, which are circulating in many of the Christian Fijian communities. According to these ideas, if 
people in Fiji do not recognise the need for God's leadership, the End-Times will bring retribution to all. A multiparty cabinet, therefore, brings with it the ambivalence and tensions of a compromise, which, in the final judgement, is not in the interests of the ACCF.

\section{Notes}

1 Research in this paper draws on the results of research conducted since 2001. The first period was funded by the School of Social and Economic Development (SSED) at the University of the South Pacific (USP), with the help of a research assistant, Akanise Tarabe. In 2003-2004, I was further funded by the School of Social Sciences and the Centre for Asia Pacific Social Transformation Studies (CAPSTRANS) at the University of Newcastle, and transcriptions were paid for by SSED, USP, in 2005. These interviews appear here for the first time. In the same year, subsequent material was gathered during research for the Pacific Theological College (PTC) and the Ecumenical Centre for Research, Education and Advocacy (ECREA), which is available in Newland, 2006, and Newland, forthcoming. This paper has benefited from the comments of Robert Norton, and the contributions/comments of Jon Fraenkel, Steve Ratuva, Jone Dakuvula, Kevin Barr, Manfred Ernst, and Jonathan Prasad.

2 Fijian Laisenia Qarase, head of the SDL (Soqosoqo Duavata ni Lewenivanua) party, was a staunch Methodist and previous Prime Minister, whereas Indo-Fijian Mahendra Chaudhry, head of the Fiji Labour Party (FLP), had been deposed in the 2000 coup.

3 New King James Version.

4 This refers most particularly to the Constitution's tolerance of homosexuality.

5 The reference to tsunamis had particular currency, given the tsunami warning issued in Suva in the early hours of 4 May 2006.

6 The Fiji Times, 10 May 2006, p.22. The same advertisement appeared in Fiji Daily Post and the Fiji Sun immediately prior to the elections (6 May 2006 and 7 May 2006, respectively). Rev. Akuila Yabaki, head of the Citizens Constitutional Forum (CCF), subsequently complained about them to the police and the Supervisor of Elections (pers.comm. Jone Dakuvula, 20 June 2006).

7 Current members are listed as: the Apostles Gospel Outreach Fellowship International (AGOFI); Assemblies of God, Fiji (AOG); Christian Mission Fellowship (CMF); Christian Outreach Centre (COC); Church of God of Fiji (COG); Covenant Evangelical Church (CEC), [formerly the Evangelical Fellowship]; Grace Baptist Church; Advanced Breakthrough Ministry $(\mathrm{ABC})$; Jesus Power Church; the Methodist Church in Fiji and Rotuma; the Methodist Davuilevu Theological College; New Life Centre; Pentecostal Churches of Fiji; Rescue Mission Fellowship; the Redeemed Christian Church of God (RCCG), the Worldwide Church of God in Fiji and Tonga; the Fiji Brethren Assemblies Partnership (Gospel Churches); the Family Life Ministry; the New Methodist Church; Fiji Baptist Convention; the Prison Chaplancy; Impact World Tour/YWAM; Prison Fellowship; Global Sports Ministries; Summit Ministries (World Views); Teach us to Pray (ministry); and Assemble Communication (ACCF, 2005). Churches that strongly diverge from these views and which remain outside the ACCF include the Roman Catholic Church, the Anglican and Presbyterian churches, the Salvation Army, the Seventh-day Adventists, the Latter-day Saints and the Jehovah's Witnesses. 
8 In this way, this paper reflects Carrithers' argument that there is a need for anthropologists to study rhetoric as a form of persuasion which draws from cultural structures to respond imaginatively to historical events (Carrithers, M. 2005. 'Why Anthropologists Should Study Rhetoric', Journal of the Royal Anthropological Institute, 11(3):577-583).

9 Thornley, A. 1996. 'The Legacy of Siloam: Tahitian Missionaries in Fiji' in Munro, D. \& Thornley, A. (eds) The Covenant Makers: Islander Missionaries in the Pacific, Pacific Theological College and IPS Publications, Suva.

10 There are various terms for this triple-aspected feature of Fijian culture. Tuwere describes it as 'the Trinitarian solemnity' (Tuwere, I.S. 2002. Vanua: Towards a Fijian Theology of Place, IPS Publications, Suva and College of St John the Evangelist, Auckland). Both Niukula and Tuwere have written booksas Methodist theologians, exploring the connections between Methodism and Fijian culture; Niukula, P. n.d. 'The triple aspect of Fijian society: the Three Pillars', Christian Writing Project, Suva.

11 For more details see, Newland, L. 2006. 'Fiji' in Ernst, M. (ed.) 2006. Globalization and the Re-Shaping of Christianity in the Pacific Islands, Pacific Theological College, Suva.

12 Given that the Methodist Church is so strongly related to Fijian culture, one of its contradictions has been its Indian Division, which, in 1996, had nearly 5,500 members (Fiji Islands Bureau of Statistics, 1996). Many Indo-Fijians left the Church after the 2000 coup, however, and up to 3,000 have since migrated and formed Methodist Indo-Fijian communities in Canada, the USA, New Zealand and Australia (Newland, 2006).

13 Garrett, J. 1990. 'Uncertain sequel: The social and religious scene in Fiji since the coups', The Contemporary Pacific, 2(1):87-111; Norton, R. 1990. Race and Politics in Fiji, St. Lucia, Qld, University of Queensland Press, Qld.

14 Garrett, J. 1997. Where Nets Were Cast: Christianity in Oceania since World War II, Institute of Pacific Studies, USP and World Council of Churches, Suva.

15 Ratuva, S. 1999. 'Ethnic Politics, Communalism and Affirmative Action in Fiji: A Critical and Comparative Study', Unpublished PhD Thesis, University of Sussex, England; Norton, R. 1990. Race and Politics in Fiji. Nadi; Ryle, J. 2001. 'My God, my land: interwoven paths of Christianity and tradition in Fiji'. Unpublished thesis, University of London; Ratuva, S. 1999. 'Ethnic Politics, Communalism and Affirmative Action in Fiji'; Ernst, M. 1994. Winds of Change: Rapidly Growing Religious Groups in the Pacific Islands, Pacific Conference of Churches, Suva; Garrett, J. 1997. Where Nets Were Cast; Garrett, J. 1990. 'Uncertain sequel'.

19 Interview with M. Lasaro, Education Officer, Methodist Church, 11 February 2004.

20 Interview with M. Lasaro, Education Officer, Methodist Church, 5 February 2004.

21 Ernst, M. 1994. Winds of Change.

22 Newland, L. 2004. 'Turning the Spirits into Witchcraft: Pentecostalism in Fijian Villages', Oceania 75(1):1-18.

23 However, the Methodist Church continues to call for a limit to new churches (e.g. The Fiji Times, 13 August 2006, p.1).

24 Fraenkel, J. 2000. 'The Clash of Dynasties and the Rise of Demagogues: Fiji's Tauir Vakaukauwa of May 2000’, Journal of Pacific History, 35(3):1-17. 
${ }^{25}$ Newland, L. 2006. 'Fiji' in Ernst, M. (ed.) 2006. Globalization and the Re-Shaping of Christianity a radical disinterest in politics. However, Speight and his former mentor, Jim Ah Koy, were both Seventh-day Adventists, and many of the villages that obeyed Speight's call from Parliament House in July 2000 for an 'uprising of the vanua' were Seventh-day Adventist villages. Speight and the brother of the former President of the Seventh-day Adventists (among others) were subsequently imprisoned (personal communication, Jon Fraenkel, Jone Dakuvula, August, 2006). Books, Auckland. Methodist Church who has recently become the Chairman of the ACCF, also described the formation of the ACCF in 2001 as a 'response to the fragmentation of indigenous communities by political parties' (Newland, L. 2006. 'Fiji').

32 Interview with Rev. Tamani, Education Officer, Christian Mission Fellowship, 12 February 2004.

33 It should be noted that the Roman Catholic Church has taken quite a different stance and has been involved in reconciliation meetings between Fijians and Indo-Fijians across the country.

34 Newland, L. (forthcoming) Social Justice in Fiji: Christian Perspectives, ECREA, Suva.

35 Coalition of Human Rights. 2005. 'Submission to CERD' in Ghand, G. (ed.) The CERD Papers: Papers on Racial Discrimination Volume 1, Fiji Institute of Applied Studies, Lautokoa; Halapua, W. 2003. Tradition, Lotu, and Militarism in Fiji.

36 History suggests a more complex picture. One of the examples Reverend Matalomani used in his discussion with me was in the allocation of land to another landless family unit who were also Fijian over 50 years ago (Newland, forthcoming). A revisiting of such laws may well mean making that family unit's descendants landless.

37 Newland, L. 2006. 'Fiji'. Kevin Barr, personal communication, 3 July 2006. The Evangelical Fellowship has been healing the land since at least 2003, when they travelled with Qarase, ACCF heads, representatives of the Great Council of Chiefs, and other officials, to Nabutautau Village, where Rev. Thomas Baker had been murdered 136 years before (Harvest Times. 2003. Healing the Land (24):20-22). Since then, 'healing the land' has become a major emphasis of the ACCF and was particularly visible prior to the elections.

Fijilive.com, 21 May 2006 'Provinces want a Christian State'

Newland, L. 2006. 'Fiji'.

There are, nonetheless, theological tensions, as Methodist leaders feel uneasy about Pentecostal/Evangelical ideas of receiving the Holy Spirit and speaking in tongues, although 
some Methodist congregations have absorbed the concept of being born again. There are also other differences between Pentecostal/Evangelical groups. For instance, as the New Life Centre is multiracial in composition, it does not accept ideas they deem discriminatory (Newland 2006).

Newland, L. 2006. 'Fiji'.

46 Newland, L. 2006. 'Fiji'.

47 Singh, M. 'PM must be Fijian: Qarase', The Fiji Times 4 May 2006, p.3. Soqosoqo Duavata ni Lewenivanua (SDL). 2006. 'Beat Poverty, Raise Prosperity', SDL Manifesto, www.sdlparty.com.fj - accessed 23 June 2006.

49 While point 3 may seem to counter-balance point 2 , respect for the indigenous community is prioritised over and above and separately from respect for other communities. In other words, some cultures are given more validity than others.

50 Newland, L. 2006. 'Fiji'.

51 Personal communication, Steve Ratuva, July 2006.

52 The ACCF was also actively involved in the legal justifications for the Promotion of Reconciliation, Tolerance, and Unity Bill (Newland 2006).

53 Newland (forthcoming).

54 The Fiji Times, 3 September 2005.

55 Letter to Director of Prosecutions from Kanaimawi Gavadi Kacimaiwai, 22 April 2005. Just after the elections, similar arguments were made about the film, The Da Vinci Code, which provoked the Methodist Church to march in Suva. See, for instance, Fijilive.com, 4 June 2006.

57 Herald Sun, 17 May 2006 'Qarase claims victory in Fiji vote'.

The Fiji Times, 2 June 2006

59 Soqosoqo Duavata ni Lewenivanua (SDL). 2006. 'Beat Poverty, Raise Prosperity', SDL Manifesto, www.sdlparty.com.fj - accessed 23 June 2006.

60 Herald Sun, 17 May 2006.

${ }^{61}$ While in the constitution, this had never been attempted before.

62 The Fiji Times, 21 May 2006.

63 The Fiji Times, 20 May 2006. 